\title{
OPEN Aluminous hydrous magnesium silicate as a lower-mantle hydrogen reservoir: a role as an agent for material transport
}

\begin{abstract}
Akihiko Nakatsuka $^{1 凶}$, Akira Yoshiasa², Makio Ohkawa ${ }^{3} \&$ Eiji Ito $^{4}$
The potential for storage of a large quantity of water/hydrogen in the lower mantle has important implications for the dynamics and evolution of the Earth. A dense hydrous magnesium silicate called phase $D$ is a potential candidate for such a hydrogen reservoir. Its $\mathrm{MgO}-\mathrm{SiO}_{2}-\mathrm{H}_{2} \mathrm{O}$ form has been believed to be stable at lower-mantle pressures but only in low-temperature regimes such as subducting slabs because of decomposition below mantle geotherm. Meanwhile, the presence of Al was reported to be a key to enhancing the thermal stability of phase D; however, the detailed Al-incorporation effect on its stability remains unclear. Here we report on Al-bearing phase D (Al-phase D) synthesized from a bridgmanite composition, with Al content expected in bridgmanite formed from a representative mantle composition, under over-saturation of water. We find that the incorporation of $\mathrm{Al}$, despite smaller amounts, into phase $\mathrm{D}$ increases its hydrogen content and moreover extends its stability field not only to higher temperatures but also presumably to higher pressures. This leads to that Al-phase $D$ can be one of the most potential reservoirs for a large quantity of hydrogen in the lower mantle. Further, Al-phase $\mathrm{D}$ formed by reaction between bridgmanite and water could play an important role in material transport in the lower mantle.
\end{abstract}

Water/hydrogen is transported into the Earth's interior via hydrous mineral phases in subducting slabs, which affects melting ${ }^{1}$ in the Earth and its rheology $y^{2-4}$. Hydrous phases as potential water/hydrogen reservoirs especially in the lower mantle have important implications for the dynamics and evolution of the Earth. A number of high-pressure studies ${ }^{5-16}$ have demonstrated that several dense hydrous magnesium silicates (DHMS) are such potential candidates. Among DHMS phases, phase D (simplified formula $\mathrm{MgSi}_{2} \mathrm{O}_{6} \mathrm{H}_{2}$ ), identical to the later reported phase $\mathrm{F}$ and phase $\mathrm{G}$, had been considered the highest-pressure phase. Later, the first principles simulations ${ }^{11}$ and high-pressure experiments ${ }^{12}$ reported the presence of phase $\mathrm{H}$ (simplified formula $\mathrm{MgSiO}_{4} \mathrm{H}_{2}$ ), a new DHMS stable at pressures higher than the stability field of phase D. A series of high-pressure experiments ${ }^{13}$ has demonstrated, however, that the $\mathrm{MgO}-\mathrm{SiO}_{2}-\mathrm{H}_{2} \mathrm{O}$ forms of these DHMS phases are stable at slab temperatures but decompose at lower temperatures than the normal mantle-geotherm.

On the other hand, the high-pressure experiments ${ }^{8}$ conducted in a bulk composition adding 1 mass $\% \mathrm{Al}_{2} \mathrm{O}_{3}$ component to the simplified phase D composition reported that phase D crystallized with several mol\% $\mathrm{Al}_{2} \mathrm{O}_{3}$ component and broke down at $\sim 1600^{\circ} \mathrm{C}$, higher temperature than in $\mathrm{Al}$-free phase $\mathrm{D}$, at $24 \mathrm{GPa}$. Super-aluminous phase $\mathrm{D}$ with extremely high $\mathrm{Al}$-content $\left(\mathrm{Mg}_{0.2} \mathrm{Fe}_{0.15} \mathrm{Al}_{1.8} \mathrm{SiO}_{6} \mathrm{H}_{1.8}\right)^{10}$ was first synthesized at $1300^{\circ} \mathrm{C}$ and 25 $\mathrm{GPa}$ from a bulk composition (including 9.8 mass $\% \mathrm{H}_{2} \mathrm{O}$ component) similar to that reported for bridgmanite formed from a mid-ocean ridge basalt (MORB) composition. The further experiment ${ }^{10}$ using the composition of this super-aluminous phase $\mathrm{D}$ produced the sample with the higher $\mathrm{H}$-content $\left(\mathrm{Mg}_{0.2} \mathrm{Fe}_{0.12} \mathrm{Al}_{1.5} \mathrm{Si}_{0.92} \mathrm{O}_{6} \mathrm{H}_{3.1}\right)$. Later, the high-pressure experiments ${ }^{9}$ in the simplified system $\mathrm{Al}_{2} \mathrm{O}_{3}-\mathrm{SiO}_{2}-\mathrm{H}_{2} \mathrm{O}$ reported that $(\mathrm{Mg}, \mathrm{Fe})$-free superaluminous phase $\mathrm{D}$ (simplified formula $\mathrm{Al}_{2} \mathrm{SiO}_{6} \mathrm{H}_{2}$ ) could be stable over $2000^{\circ} \mathrm{C}$ at $26 \mathrm{GPa}$. Phase $\mathrm{H}$ can also incorporate a large amount of $\mathrm{Al}$, forming a solid solution with $\delta$ - $\mathrm{AlOOH}^{15,16}$. The high-pressure experiments ${ }^{16}$ conducted in a bulk composition of $0.70 \mathrm{MgSiO}_{3} \cdot 0.30 \mathrm{Al}_{2} \mathrm{O}_{3}$ with $1.5-7.0$ mass $\% \mathrm{H}_{2} \mathrm{O}$ component showed that the aluminous phase $\mathrm{H}(\mathrm{Al}$-phase $\mathrm{H})$ was produced with more than $50 \mathrm{~mol} \% \mathrm{Al}_{2} \mathrm{O}_{4} \mathrm{H}_{2}$ component and could be stable even along the normal lower-mantle geotherm at $>40 \mathrm{GPa}$. In addition, these experiments showed that

${ }^{1}$ Graduate School of Sciences and Technology for Innovation, Yamaguchi University, Ube 755-8611, Japan. ${ }^{2}$ Faculty of Advanced Science and Technology, Kumamoto University, Kumamoto 860-8555, Japan. ${ }^{3}$ Graduate School of Advanced Science and Engineering, Hiroshima University, Higashi-Hiroshima 739-8526, Japan. ${ }^{4}$ Institute for Planetary Materials, Okayama University, Misasa 682-0193, Japan. ${ }^{凶}$ email: tuka@yamaguchi-u.ac.jp 


\begin{tabular}{|l|l|l|l|l|l|l|}
\hline Run no. & Starting materials & $\boldsymbol{P}(\mathbf{G P a})$ & $\boldsymbol{T}_{\text {max }}\left({ }^{\circ} \mathbf{C}\right)$ & Duration at $\boldsymbol{T}_{\max }(\mathbf{m i n})$ & $\boldsymbol{T}_{\mathbf{q}}\left({ }^{\circ} \mathbf{C}\right)$ & $\begin{array}{l}\text { Cooling rate from } \boldsymbol{T}_{\max } \text { to } \boldsymbol{T}_{\mathbf{q}} \\
\left({ }^{\circ} \mathbf{C} / \text { min }\right)\end{array}$ \\
\hline$\# 1$ & $\mathrm{MgO}, \mathrm{SiO}_{2}, \mathrm{Al}(\mathrm{OH})_{3}, \mathrm{H}_{2} \mathrm{O}$ & 27 & 1600 & 10 & 1600 & No cooling \\
\hline$\# 2$ & $\mathrm{Mg}(\mathrm{OH})_{2}, \mathrm{SiO}_{2}, \mathrm{Al}(\mathrm{OH})_{3}, \mathrm{H}_{2} \mathrm{O}$ & 27 & 1900 & 5 & 1600 & 50 \\
\hline$\# 3$ & $\mathrm{MgO}, \mathrm{SiO}_{2}, \mathrm{Al}(\mathrm{OH})_{3}, \mathrm{H}_{2} \mathrm{O}$ & 26 & 1900 & 10 & 1300 & 30 \\
\hline
\end{tabular}

Table 1. Conditions of the high-pressure experiments. $T_{\text {max }}$ target maximum temperature, $T_{q}$ quenching temperature.

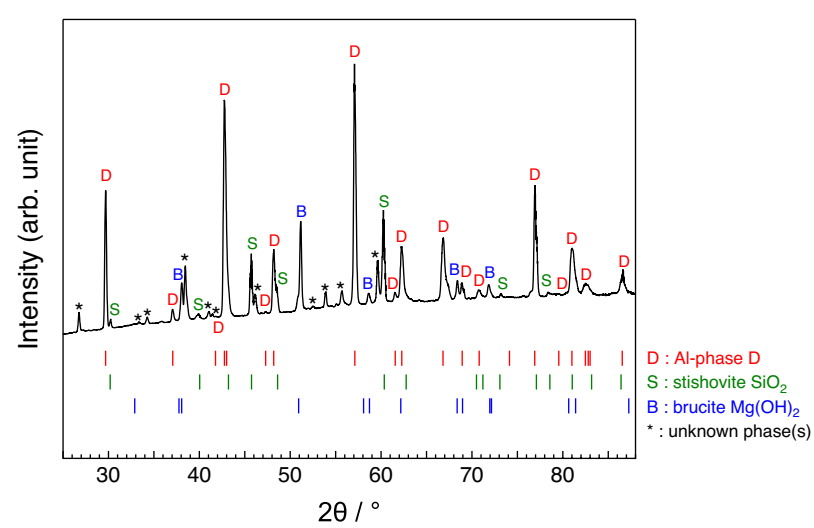

Figure 1. Microfocus powder X-ray diffraction pattern of a recovered sample. As an example, that of the run \#2 is given here.

it could be stable to $\sim 130 \mathrm{GPa}$, corresponding to a pressure at the lowermost mantle, along a subducting slab geotherm. Thus, the presence of $\mathrm{Al}$ is a potential key-factor for enhancing the thermal stability of these DHMS phases at the lower-mantle pressures. The recent high-pressure experiments ${ }^{16-18}$ demonstrated that $\mathrm{Al}$ ions are much more preferentially partitioned into hydrous phases (phase D or phase $\mathrm{H}$ ) than anhydrous phases (bridgmanite or post-perovskite phase); this situation was observed even in Al-poor bulk-compositions ${ }^{17}$ such as peridotitic (or pyrolitic) composition. This suggests that under the presence of suitable water amount, the aluminous hydrous phases with high stability could exist not only in Al-rich fields such as MORB of subducting slabs but also everywhere in the lower mantle. However, the crystal-chemical mechanism for the stability enhancement of these hydrous phases due to the incorporation of $\mathrm{Al}$ remains to be solved. Here we report on Al-bearing phase $\mathrm{D}$ (Al-phase $\mathrm{D}$ ) synthesized from high-pressure experiments of a bridgmanite composition in the system $\mathrm{MgO}-\mathrm{SiO}_{2}-\mathrm{Al}_{2} \mathrm{O}_{3}$, with $\mathrm{Al}$ content close to that reported for bridgmanite formed from a representative mantle composition, under over-saturation of water. We reveal the incorporation mechanism of $\mathrm{Al}$ and a large amount of hydrogen $(\mathrm{H})$ into phase $\mathrm{D}$ and demonstrate the drastic enhancement in stability of phase $\mathrm{D}$ due to the incorporation of a relatively small amount of Al. We discuss the mechanism for such a high stability of Alphase $\mathrm{D}$, in terms of crystal chemistry based on single-crystal X-ray diffraction. On the basis of these findings, we propose crucial implications for the recycle of water in the lower mantle.

We selected the starting composition of $0.92 \mathrm{MgSiO}_{3} \cdot 0.08 \mathrm{Al}_{2} \mathrm{O}_{3}$ because it is close to the composition of bridgmanite, $0.94 \mathrm{MgSiO}_{3} \cdot 0.06 \mathrm{Al}_{2} \mathrm{O}_{3}$ (Refs. ${ }^{19,20}$ ), expected in a pyrolitic ${ }^{21}$ lower-mantle. Our high-pressure experiments were conducted under the three different thermal histories. Their experimental conditions are summarized in Table 1. Reagent grade oxides and hydroxides were mixed in the required ratios and sealed in platinum $(\mathrm{Pt})$ capsules together with amounts of liquid water suitable for over-saturation. The samples were compressed to $27 \mathrm{GPa}$ (runs \#1 and \#2) or $26 \mathrm{GPa}$ (run \#3) and then heated to each target maximum temperature of $1600^{\circ} \mathrm{C}$ (run \#1) or $1900^{\circ} \mathrm{C}$ (runs \#2 and \#3) using a Kawai-type multi-anvil apparatus ${ }^{22}$. After undergoing each thermal history, the samples were quenched at $1600{ }^{\circ} \mathrm{C}$ (runs \#1 and \#2) or $1300{ }^{\circ} \mathrm{C}$ (run \#3) and recovered to ambient conditions. In all the runs, liquid water was seeping out of the Pt capsules when those were opened, which shows that the recovered samples were synthesized under over-saturation of water.

We measured the microfocus X-ray diffraction patterns for the recovered samples of the runs \#1 and \#2. A typical example of them is shown in Fig. 1. In the patterns, we observed the diffraction peaks corresponding to phase $\mathrm{D}$, stishovite $\mathrm{SiO}_{2}$ and brucite $\mathrm{Mg}(\mathrm{OH})_{2}$. The peaks that cannot be assigned to any known-phases were also observed; these are probably due to impurities precipitated, together with brucite, from fluid during quenching. Here, we determined the unit-cell parameters with trigonal symmetry by least-squares fits of the $d$ spacings of 21 peaks assigned to phase $\mathrm{D}$ as follows: $a=4.8239(1) \AA, c=4.3134(2) \AA, V=86.924(4) \AA^{3}$ for the run \#1; $a=4.8416(1) \AA, c=4.3236(2) \AA, V=87.771(4) \AA^{3}$ for the run \#2. The calculated $d$ values of these peaks are in good agreement with the observed ones (Table 2 ).

To confirm the presence of phase $\mathrm{D}$, we conducted the electron probe microanalyses for the recovered sample of the run \#1. The analytical result showed the presence of products with a chemical composition of $23.11 \mathrm{mass} \%$ $\mathrm{MgO}, 42.97$ mass $\% \mathrm{SiO}_{2}$ and 18.66 mass $\% \mathrm{Al}_{2} \mathrm{O}_{3}$ with a total of 84.74 mass\%. This phase was damaged by the 


\begin{tabular}{|c|c|c|c|c|c|c|c|c|}
\hline \multirow{2}{*}{$\begin{array}{l}\text { Sample } \\
h k l\end{array}$} & \multicolumn{4}{|c|}{ Run \# 1} & \multicolumn{4}{|c|}{ Run \#2 } \\
\hline & $I / I_{0}$ & $d_{\text {obs }}(\AA)$ & $d_{\text {cal }}(\AA)$ & $d_{\mathrm{obs}}-d_{\mathrm{cal}}(\AA)$ & $I / I_{0}$ & $d_{\text {obs }}(\AA)$ & $d_{\text {cal }}(\AA)$ & $d_{\mathrm{obs}}-d_{\text {cal }}(\AA)$ \\
\hline 101 & 25 & 2.9964 & 3.0009 & -0.0045 & 47 & 3.0088 & 3.0100 & -0.0012 \\
\hline 110 & $<1$ & 2.4169 & 2.4119 & 0.0050 & 5 & 2.4254 & 2.4208 & 0.0046 \\
\hline 002 & 2 & 2.1543 & 2.1567 & -0.0024 & $<1$ & 2.1625 & 2.1618 & 0.0007 \\
\hline 111 & 35 & 2.1096 & 2.1052 & 0.0044 & 83 & 2.1145 & 2.1123 & 0.0022 \\
\hline 200 & 33 & 2.0932 & 2.0888 & 0.0044 & 38 & 2.1030 & 2.0965 & 0.0065 \\
\hline 102 & $<1$ & 1.9177 & 1.9164 & 0.0013 & $<1$ & 1.9219 & 1.9214 & 0.0005 \\
\hline 201 & 45 & 1.8803 & 1.8800 & 0.0003 & 26 & 1.8888 & 1.8864 & 0.0024 \\
\hline 112 & 100 & 1.6074 & 1.6077 & -0.0003 & 100 & 1.6129 & 1.6124 & 0.0005 \\
\hline 202 & 3 & 1.5036 & 1.5004 & 0.0032 & 4 & 1.5065 & 1.5050 & 0.0015 \\
\hline 211 & 44 & 1.4892 & 1.4828 & 0.0064 & 23 & 1.4910 & 1.4880 & 0.0030 \\
\hline 300 & 9 & 1.3914 & 1.3925 & -0.0011 & 35 & 1.4002 & 1.3977 & 0.0025 \\
\hline 103 & 11 & 1.3588 & 1.3595 & -0.0007 & 8 & 1.3624 & 1.3629 & -0.0005 \\
\hline 301 & 5 & 1.3298 & 1.3252 & 0.0046 & 5 & 1.3309 & 1.3299 & 0.0010 \\
\hline 212 & 1 & 1.2732 & 1.2740 & -0.0008 & $<1$ & 1.2790 & 1.2781 & 0.0009 \\
\hline 113 & 10 & 1.2351 & 1.2350 & 0.0001 & 28 & 1.2396 & 1.2384 & 0.0012 \\
\hline 220 & 1 & 1.2084 & 1.2060 & 0.0024 & $<1$ & 1.2049 & 1.2104 & -0.0055 \\
\hline 203 & 3 & 1.1858 & 1.1843 & 0.0015 & 24 & 1.1872 & 1.1876 & -0.0004 \\
\hline 302 & 4 & 1.1653 & 1.1699 & -0.0046 & 9 & 1.1695 & 1.1737 & -0.0042 \\
\hline 221 & $<1$ & 1.1595 & 1.1614 & -0.0019 & $<1$ & 1.1658 & 1.1656 & 0.0002 \\
\hline 310 & 3 & 1.1549 & 1.1587 & -0.0038 & 3 & 1.1636 & 1.1629 & 0.0007 \\
\hline 311 & 5 & 1.1199 & 1.1190 & 0.0009 & 12 & \begin{tabular}{|l|}
1.1247 \\
\end{tabular} & 1.1230 & 0.0017 \\
\hline
\end{tabular}

Table 2. Microfocus X-ray diffraction data for Al-phase $D$ in the recovered samples of the runs \#1 and \#2. Calculated unit-cell parameters and volumes: $a=4.8239$ (1) $\AA, c=4.3134(2) \AA, V=86.924(4) \AA^{3}$ for the run \#1; $a=4.8416(1) \AA, c=4.3236(2) \AA, V=87.771(4) \AA^{3}$ for the run \#2.

electron beam. The deficiency ( 15.26 mass\%) from 100 mass\% is attributed to the incorporation of $\mathrm{H}_{2} \mathrm{O}$ component into the structure, and the chemical formula of the products was calculated to be $\mathrm{Mg}_{1.01} \mathrm{Si}_{1.26} \mathrm{Al}_{0.65} \mathrm{O}_{6} \mathrm{H}_{2.99}$. From the compatibility with phase $\mathrm{D}^{5,23-25}$ in terms of unit-cell parameters and chemical formula, it is concluded thus that the present hydrous phase is $\mathrm{Al}$-phase $\mathrm{D}$. These results obtained from the samples quenched at $1600{ }^{\circ} \mathrm{C}$ at $27 \mathrm{GPa}$, lying in the normal mantle-geotherm, substantiates that phase $\mathrm{D}$ is stable even at the conditions corresponding to the uppermost parts in the lower mantle if it contains some amount of $\mathrm{Al}_{2} \mathrm{O}_{3}$ component, in contrast to Al-free phase $\mathrm{D}$, which decomposes at $1200{ }^{\circ} \mathrm{C}\left(\right.$ Ref. $\left.^{7}\right)$.

To assess why the presence of $\mathrm{Al}$ drastically enhances the stability of phase $\mathrm{D}$, it is quite important to determine the detailed crystal structure of Al-phase D. The slow cooling from higher temperatures is effective to enhance crystal growth from melt, as in the case of $\mathrm{Al}$-free $\mathrm{MgSiO}_{3}$ bridgmanite ${ }^{26}$. The runs \#2 and \#3, with the slow cooling from $1900^{\circ} \mathrm{C}$, were thus conducted to try synthesis of Al-phase D single-crystals large enough for single-crystal X-ray diffraction. Numerous transparent and euhedral single-crystals (Fig. 2), which possess a crystal habit implying a trigonal or a hexagonal symmetry, were found in the recovered samples. No intergrowth textures were observed under polarized microscope. A specimen for single-crystal X-ray diffraction was selected from the crystals produced in the run \#3, with the slower cooling rate than in the run \#2, because they were better in terms of size and crystallinity than those produced in the run \#2. The electron probe microanalyses for the crystals produced in the run \#3 showed a chemical composition of 28.46 mass $\% \mathrm{MgO}, 48.69 \mathrm{mass}_{2} \mathrm{SiO}_{2}$ and 7.72 mass $\% \mathrm{Al}_{2} \mathrm{O}_{3}$ with a total of 84.87 mass\% to give a chemical formula of $\mathrm{Mg}_{1.25} \mathrm{Si}_{1.43} \mathrm{Al}_{0.27} \mathrm{O}_{6} \mathrm{H}_{2.97}$ by assigning the deficit from 100 mass\% to $\mathrm{H}_{2} \mathrm{O}$ component. This composition differs somewhat from that in the run \#1 shown above. This is probably due to the difference in thermal history and/or water fugacity, which can influence $\mathrm{Mg} /$ Si ratio in fluid, between the two runs.

The crystal structure determined for the selected crystal (run \#3) are shown in Fig. 3a-c, together with the residual electron density peak (Fig. 3d) assigned to a hydrogen $(\mathrm{H})$ atom. The structure-analytical information and results are given in Supplementary Table S1, and Tables 3 and 4. The M-O bond length [2.113(2) $\AA$ ] in the present Al-phase D single-crystal $\left(\mathrm{Mg}_{1.25} \mathrm{Si}_{1.43} \mathrm{Al}_{0.27} \mathrm{O}_{6} \mathrm{H}_{2.97}\right)$ agrees excellently with that $\left[2.114(3) \AA^{3}\right]$ in the reported Al-free phase $\mathrm{D}\left(\mathrm{Mg}_{1.24} \mathrm{Si}_{1.76} \mathrm{O}_{6} \mathrm{H}_{2.48}\right)^{24}$, whereas the S-O bond length [1.840(1) $\AA$ ] in the former is significantly larger than that $[1.823(2) \AA]$ in the latter. This shows that larger $\mathrm{Al}^{3+}$ is incorporated only into $\mathrm{S}$-site and substitutes smaller $\mathrm{Si}^{4+}$, justifying the present site-assignment of Al. Indeed, bond valence sums ${ }^{27}$, calculated including $\mathrm{H}-\mathrm{O}$ (donor) and $\mathrm{H}$-.. O (acceptor) bonds, are 1.88 for M-site, 3.42 for S-site and 2.02 for O-site, approximately equal to their expected values (1.96, 3.54 and 2.0, respectively), demonstrating that the resulting positional parameters and site occupancy parameters are crystal-chemically reasonable.

Owing to the constraints of the space group, a pair of centrosymmetric $\mathrm{H}$ positions (Wyckoff position $6 k$ ) are present in close proximity $(\mathrm{H} \cdots \mathrm{H}=1.07 \AA$ ) (Fig. 3c, Table 4). If an $\mathrm{H}$ position is occupied, its nearest $\mathrm{H}$ position must be unoccupied to avoid an $\mathrm{H}^{+}-\mathrm{H}^{+}$interaction (Fig. 3c). Thus, the maximum allowance for the number of $\mathrm{H}$ atoms contained in a unit cell is 3 , corresponding to a half occupancy of the $6 k$-site. The $\mathrm{H}$ content of the 


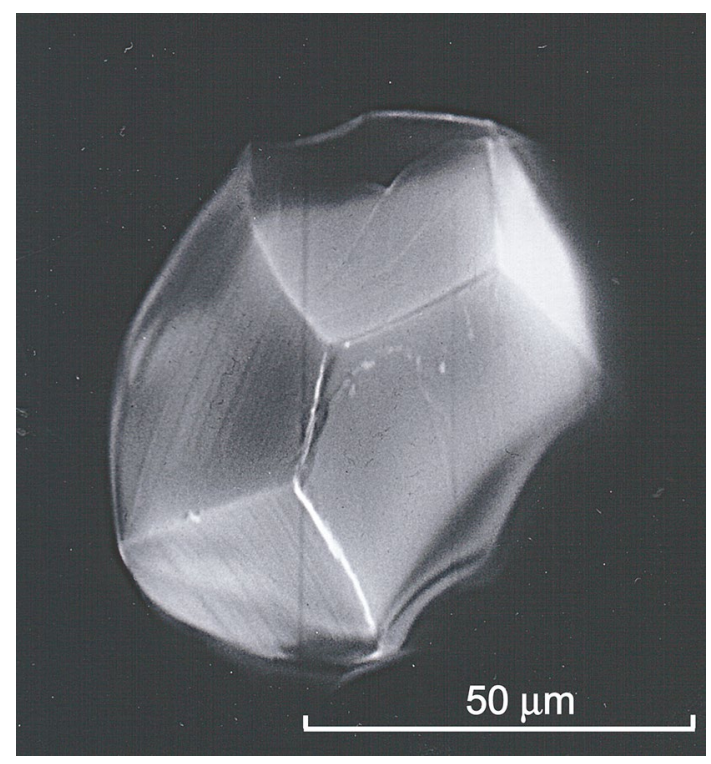

Figure 2. Scanning electron microscope image of a synthesized Al-phase D single-crystal. As an example, that of the run \#3 is given here.

present Al-phase $\mathrm{D}(2.97-2.99 \mathrm{H}$ atoms per unit cell) is very close to the maximum allowance. The comparison of the cation ratios of Al-free phase $\mathrm{D}\left(\mathrm{Mg}_{1.11-1.24} \mathrm{Si}_{1.73-1.89} \mathrm{O}_{6} \mathrm{H}_{2.22-2.81}\right)^{5,23-25}$ with those of the present Al-phase D shows that the substitution $\mathrm{Si}^{4+} \rightarrow \mathrm{Al}^{3+}+\mathrm{H}^{+}$, in addition to $\mathrm{Si}^{4+} \rightarrow \mathrm{Mg}^{2+}+2 \mathrm{H}^{+}$and $\mathrm{Mg}^{2+} \rightarrow 2 \mathrm{H}^{+}+\mathrm{Vc}$ (Vc: cation vacancy) suggested for $\mathrm{Al}$-free phase $\mathrm{D}^{5}$, is responsible for a larger amount of $\mathrm{H}$ in Al-phase $\mathrm{D}$. The contents of $\mathrm{Al}^{3+}, \mathrm{Si}^{4+}, \mathrm{Mg}^{2+}$ and $\mathrm{Vc}$ in $\mathrm{Al}$-phase $\mathrm{D}$ are adjusted under the constraint that the number of $\mathrm{H}^{+}$per unit cell must be equal to or less than 3 .

In Fig. 4, possible phase relations for pure $\mathrm{MgSiO}_{3}$ (dotted grey lines) and $\mathrm{Al}_{2} \mathrm{O}_{3}$-bearing $\mathrm{MgSiO}_{3}$ (solid blue lines) under water-saturated conditions are shown together with the slow-cooling paths (solid red arrows) adopted for our crystal-growth experiments. As the liquidus temperature of $\mathrm{MgSiO}_{3}$ at $27 \mathrm{GPa}$ under water saturation is $1750{ }^{\circ} \mathrm{C}\left(\right.$ Ref. $\left.^{26}\right)$, our charges would have been above liquidus when kept at $1900{ }^{\circ} \mathrm{C}$ in the crystalgrowth experiments, in spite of a slight increase of the liquidus due to the $\mathrm{Al}_{2} \mathrm{O}_{3}$ component ${ }^{28}$. Thus, it is inferred that the single crystals of $\mathrm{Al}$-phase $\mathrm{D}$ grew from melt. This view is supported by the fact that the crystals have a perfect euhedral-shape (see Fig. 2) and exhibit no intergrowth texture; these observations exclude the possibility that the crystals are product of reaction involving any other phases, such as Al-bearing $\mathrm{MgSiO}_{3}$ bridgmanite (Al-Brg). It is therefore concluded that Al-phase D is stable up to temperatures substantially higher than the normal mantle-geotherm. Moreover, as Al-phase D crystallized from a starting material with the composition of Al-Brg, the former should be more stable than the latter under water-saturated conditions.

Such a drastic change in stability relations between bridgmanite and phase $\mathrm{D}$ under water-saturated conditions by addition of a relatively small amount of $\mathrm{Al}_{2} \mathrm{O}_{3}$ component is interpreted in terms of the difference in the coordination environments of $\mathrm{Al}$ ions between $\mathrm{Al}-\mathrm{Brg}$ and $\mathrm{Al}$-phase $\mathrm{D}$. The $\mathrm{Al}$ ions in $\mathrm{Al}-\mathrm{Brg}$ occupy both the eightfold- and sixfold-coordinated sites by the substitution ${ }^{\mathrm{VIII}} \mathrm{Mg}^{2+}+{ }^{\mathrm{VI}} \mathrm{Si}^{4+} \rightarrow{ }^{\mathrm{VIII}} \mathrm{Al}^{3+}+{ }^{\mathrm{VI}} \mathrm{Al}^{3+}\left(\mathrm{Ref}^{29}\right)$. Eightfold coordination is unsuitable for $\mathrm{Al}^{3+}$ because of its small cationic size; indeed, no compound with eightfold-coordinated $\mathrm{Al}$ is known except for $\mathrm{Al}-\mathrm{Brg}$. Such an unusual eightfold-coordinated $\mathrm{Al}$ should enhance the cohesive energy of $\mathrm{Al}-\mathrm{Brg}$, and the repulsive interaction with adjacent $\mathrm{Si}^{4+}$ or $\mathrm{Al}^{3+}$ through the shared faces between ( $\mathrm{Si}$, $\mathrm{Al}) \mathrm{O}_{6}$-octahedra and $(\mathrm{Mg}, \mathrm{Al}) \mathrm{O}_{8}$-polyhedra may especially tend to destabilize the structure. In contrast, the incorporation of $\mathrm{Al}$ into phase $\mathrm{D}$ will reduce the cation-cation repulsion across the shared edges between $(\mathrm{Si}, \mathrm{Al}$, $\mathrm{Mg}) \mathrm{O}_{6}$-octahedra in S-site (Fig. 3a,b) by the substitution of $\mathrm{Al}^{3+}$ for $\mathrm{Si}^{4+}$, owing to the lower charge and larger cationic size of $\mathrm{Al}^{3+}$. Thus, the incorporation of $\mathrm{Al}$ into phase $\mathrm{D}$ results in expansion of the stability field to much higher temperatures and presumably to much higher pressures.

It follows from this discussion that phase $\mathrm{D}$ could be stable along the normal lower-mantle geotherm up to much higher pressures if it contains some amount of $\mathrm{Al}_{2} \mathrm{O}_{3}$ component (cf. Fig. 4). Bridgmanite in the lower mantle probably contains about $6 \mathrm{~mol} \% \mathrm{Al}_{2} \mathrm{O}_{3}$ component ${ }^{19,20}$, and $\mathrm{Al}$-phase $\mathrm{D}$ in the lower mantle could form by reaction between bridgmanite and free water. Given that the representative formula of $\mathrm{Al}$-phase $\mathrm{D}$ is $\mathrm{MgSi}_{2-x} \mathrm{Al}_{x} \mathrm{O}_{6} \mathrm{H}_{2+x}$, the reaction can be expressed as follows:

$$
\begin{aligned}
& x \mathrm{Mg}_{0.94} \mathrm{Si}_{0.94} \mathrm{Al}_{0.12} \mathrm{O}_{3}(\mathrm{Al}-\mathrm{Brg})+(0.06 x+0.12) \mathrm{H}_{2} \mathrm{O} \\
& \quad \rightarrow 0.12 \mathrm{MgSi}_{2-x} \mathrm{Al}_{x} \mathrm{O}_{6} \mathrm{H}_{2+x}(\mathrm{Al} \text {-phase } \mathrm{D})+(0.94 x-0.12) \mathrm{MgO}+(1.06 x-0.24) \mathrm{SiO}_{2} .
\end{aligned}
$$

Bolfan-Casanova et al. ${ }^{30}$ demonstrated that the major lower-mantle constituents, bridgmanite and ferropericlase

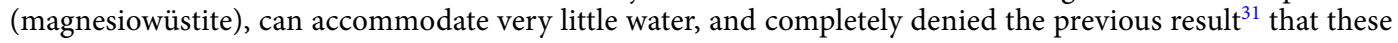


a

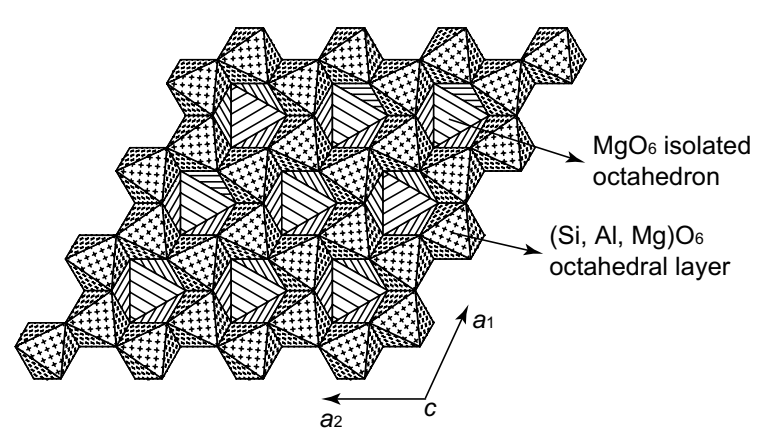

C

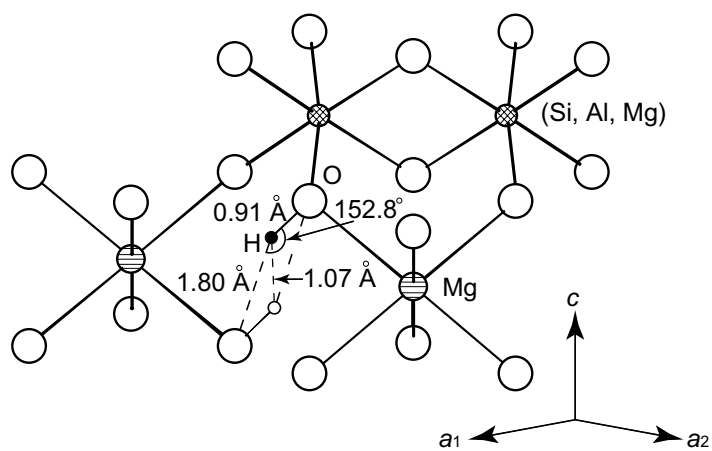

b

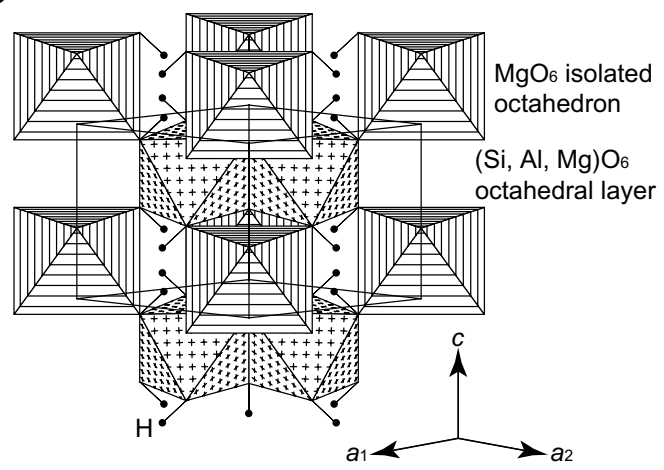

d

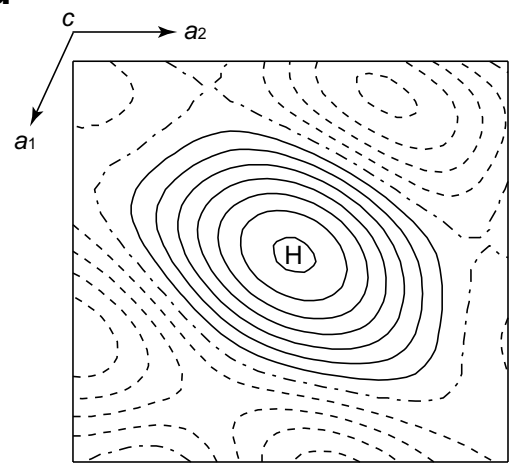

Figure 3. Crystal structure of the present $\mathrm{Al}$-phase $\mathrm{D}$, analyzed using a single-crystal produced in the run \#3. (a) Projection along the $c$-axis (excluding $\mathrm{H}$ atoms). (b) Projection along the direction close to [110]. $\mathrm{H}$ site is denoted with small solid circles. In the present $\mathrm{Al}$-phase $\mathrm{D}, \mathrm{H}$ atoms occupy about $50 \%$ of this site. The crystal structure is based on the hexagonal closest packing array of $\mathrm{O}$ atoms and consists of the two types of octahedra, ( $\mathrm{Si}, \mathrm{Al}, \mathrm{Mg}$ ) $\mathrm{O}_{6}$-octahedra in S-site and $\mathrm{MgO}_{6}$-octahedra in $\mathrm{M}$-site. The ( $\mathrm{Si}, \mathrm{Al}, \mathrm{Mg}$ ) $\mathrm{O}_{6}$-octahedra form the layer structure by sharing edges with each other, and the layers are stacked along the $c$-axis. The $\mathrm{MgO}_{6}$-octahedra, isolated with each other, connect the separations between the $(\mathrm{Si}, \mathrm{Al}, \mathrm{Mg}) \mathrm{O}_{6}$-octahedral layers by sharing corners with the ( $\mathrm{Si}, \mathrm{Al}, \mathrm{Mg}) \mathrm{O}_{6}$-octahedra. The hydrogen bonds contribute to the linkages between the $\mathrm{MgO}_{6}$ octahedra and between the $\mathrm{MgO}_{6}$ - and the ( $\mathrm{Si}, \mathrm{Al}, \mathrm{Mg}$ ) $\mathrm{O}_{6}$-octahedra. (c) Crystallographic configuration of $\mathrm{H}$ atom. The small solid circle is an occupied H-position, and the small open circle is an unoccupied H-position. (d) Difference Fourier map denoting the residual electron density peak assigned to a $\mathrm{H}$ atom. The contour interval is $0.05 \mathrm{e}^{-3}$. Positive contours are solid lines. Negative and zero contours are dashed lines and dashedand-dotted lines, respectively.

nominally anhydrous phases could contain $0.2-0.4$ mass $\% \mathrm{H}_{2} \mathrm{O}$ component. Thus, the Al-phase $\mathrm{D}$ is a phase with potential as a reservoir of a large quantity of hydrogen in the normal lower-mantle.

MORB component of subducting slabs has $\mathrm{Al}_{2} \mathrm{O}_{3}$ content higher than pyrolite, and in the lower mantle bridgmanite with about $15-16$ mass $\% \mathrm{Al}_{2} \mathrm{O}_{3}$ component is stable in this composition ${ }^{32,33}$. This $\mathrm{Al}_{2} \mathrm{O}_{3}$ content is higher than that (about 8 mass\%) in the bridgmanite composition employed in the present high-pressure experiments. Therefore, phase $\mathrm{D}$ in slabs would contain a large amount of $\mathrm{Al}_{2} \mathrm{O}_{3}$ component, and this content would be higher than that in the present Al-phase D. Indeed, super-aluminous phase D (simplified formula $\mathrm{Al}_{2} \mathrm{SiO}_{6} \mathrm{H}_{2}$ ), which could be stable over $2000{ }^{\circ} \mathrm{C}$ at $26 \mathrm{GPa}$ (Ref. ${ }^{9}$ ), was produced from the similar Al-rich bulk composition $^{10}$. If the incorporation of $\mathrm{Al}$ into phase $\mathrm{D}$ extends its stability field to higher pressure following the above crystal-chemical prediction, then Al-phase $\mathrm{D}$ in slabs can carry hydrogen much deeper in the lower mantle than previously estimated ${ }^{7,34}$. This speculation is consistent with the phase relation reported in the simplified system such as $\mathrm{MgO}-\mathrm{Al}_{2} \mathrm{O}_{3}-\mathrm{SiO}_{2}-\mathrm{H}_{2} \mathrm{O}$ (Ref. ${ }^{17}$ ), but is inconsistent with that reported recently in the hydrous MORB system ${ }^{35}$. It was reported that in the former systems ${ }^{17} \mathrm{Al}$-phase $\mathrm{D}$ was stable up to $\sim 55 \mathrm{GPa}$ and Al-phase $\mathrm{H}$ was the stable hydrous phase at higher pressures, whereas in the latter system ${ }^{35}$ the stable region of Al-phase D was drastically reduced to $25 \mathrm{GPa}$. This discrepancy in the stability relation of the hydrous phases may be attributed to the difference in the staring compositions including water contents, but the details remain to be solved. Even if Al-phase D decomposes into Al-phase $\mathrm{H}$ at lower pressures in actual subducting-slabs as suggested in the recent study ${ }^{35}$, hydrogen should be transported still deeper in the lower mantle by Al-phase $\mathrm{H}$, stable up to much higher pressures ${ }^{16}$. The ultimately released water would be hardly absorbed into the surrounding lower-mantle constituents and be stored as hydroxyl groups in Al-phase D in the upper region of the lower mantle according to the reaction (1), although Al-phase $\mathrm{H}$ produced by reaction with bridgmanite might intervene depending on depth as will discussed below. 


\begin{tabular}{|l|l|l|l|l|}
\hline Site (W.p.) & $\mathbf{M}(\mathbf{1} \boldsymbol{a})$ & $\mathbf{S}(\mathbf{2} \boldsymbol{d})$ & $\mathbf{O}(\mathbf{6} \boldsymbol{k})$ & $\mathbf{H}(\mathbf{6 k})^{\mathbf{b}}$ \\
\hline \multirow{3}{*}{ Occupancy } & \multirow{3}{*}{$0.979(8) \mathrm{Mg}^{\mathrm{a}}$} & $0.715 \mathrm{Si}^{\mathrm{a}}$ & & \\
\cline { 3 - 4 } & & $0.135 \mathrm{Al}^{\mathrm{a}}$ & \multirow{2}{*}{1.0} & \multirow{2}{*}{0.495} \\
\cline { 3 - 4 } & $0.135 \mathrm{Mg}^{\mathrm{a}}$ & & \\
\hline$x$ & 0 & 0.3333 & $0.6340(5)$ & 0.495 \\
\hline$y$ & 0 & 0.6667 & 0 & 0 \\
\hline$z$ & 0 & 0.5 & $0.2669(4)$ & 0.124 \\
\hline$U_{\mathrm{eq}}\left(\AA^{2}\right)$ & $0.0130(12)$ & $0.0101(7)$ & $0.0132(17)$ & - \\
\hline$U_{11}\left(\AA^{2}\right)$ & $0.0136(12)$ & $0.0108(7)$ & $0.0128(12)$ & - \\
\hline$U_{22}\left(\AA^{2}\right)$ & 0.0136 & 0.0108 & $0.0208(15)$ & - \\
\hline$U_{33}\left(\AA^{2}\right)$ & $0.0118(16)$ & $0.0085(9)$ & $0.0085(11)$ & - \\
\hline$U_{12}\left(\AA^{2}\right)$ & 0.0068 & 0.0054 & 0.0104 & - \\
\hline$U_{13}\left(\AA^{2}\right)$ & 0 & 0 & $-0.0002(7)$ & - \\
\hline$U_{23}\left(\AA^{2}\right)$ & 0 & 0 & 0 & - \\
\hline
\end{tabular}

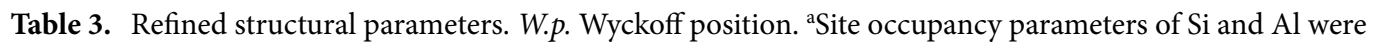
fixed on S-site, and those of Mg were constrained between M- and S-sites to keep the chemical composition from the electron probe microanalyses. ${ }^{b} \mathrm{H}$-atom position was determined from the difference Fourier synthesis, and not refined.

\begin{tabular}{|l|l|l|}
\hline Bonds/separations & Distances $(\AA \AA)$ & Angles $\left(^{\circ}\right)$ \\
\hline $\mathrm{M}-\mathrm{O}$ & $2.113(2) \times 6$ & - \\
\hline $\mathrm{S}-\mathrm{O}$ & $1.840(1) \times 6$ & - \\
\hline $\mathrm{H}-\mathrm{O}$ (donor) & 0.913 & - \\
\hline $\mathrm{H} \cdots \mathrm{O}$ (acceptor) & 1.802 & - \\
\hline $\mathrm{H} \cdots \mathrm{H}$ & 1.073 & - \\
\hline $\mathrm{O}-\mathrm{H} \cdots \mathrm{O}$ & - & 152.84 \\
\hline
\end{tabular}

Table 4. Selected interatomic distances and angles.

The role of Al-phase $\mathrm{D}$ in the dynamics of the lower mantle is especially noteworthy. The zero-pressure/roomtemperature density of the present Al-phase $\mathrm{D}$ is calculated to be $\rho_{0}=3.35 \mathrm{~g} / \mathrm{cm}^{3}$. Although the incorporation of Fe into Al-phase D can affect $\rho_{0}$, the reported values $\left(3.45-3.56 \mathrm{~g} / \mathrm{cm}^{3}\right)$ of Al-phase D containing some amount of $\mathrm{FeO} / \mathrm{Fe}_{2} \mathrm{O}_{3}$ component $\left(\mathrm{Mg}_{0.89-1.0} \mathrm{Fe}_{0.11-0.15} \mathrm{Al}_{0.03-0.32} \mathrm{Si}_{1.5-1.9} \mathrm{O}_{6} \mathrm{H}_{2.5-2.93}\right)^{36-39}$ are only a little higher than that of the present Al-phase D. These $\rho_{0}$ values, including the present data, are all considerably lower than the representative value of the lower-mantle $\rho_{0}=4.15 \mathrm{~g} / \mathrm{cm}^{3}\left(\right.$ Ref. $\left.^{40}\right)$. Therefore, a "wet-metasomatized" region containing $\mathrm{Al}$-phase D would move upward owing to pronounced buoyancy even if it contains some amount of $\mathrm{FeO} / \mathrm{Fe}_{2} \mathrm{O}_{3}$ component. Similarly, the $\rho_{0}$ value of $(\mathrm{Al}, \mathrm{Fe})$-free phase $\mathrm{H}$ is $3.38 \mathrm{~g} / \mathrm{cm}^{3}\left(\mathrm{Ref}^{41}\right)$, very close to that $\left(3.43 \mathrm{~g} / \mathrm{cm}^{3}\right)^{24}$ of $\left(\mathrm{Al}, \mathrm{Fe}\right.$ )-free phase $\mathrm{D}$; containing of some amount of $\mathrm{Al}_{2} \mathrm{O}_{3}$ and/or $\mathrm{FeO} / \mathrm{Fe}_{2} \mathrm{O}_{3}$ components will not yield a significant increase in $\rho_{0}$ of phase $\mathrm{H}$ as well [cf. $\rho_{0}=3.54 \mathrm{~g} / \mathrm{cm}^{3}$ for $\delta$-AlOOH (Refs. $\left.{ }^{42,43}\right) ; \rho_{0}=4.45 \mathrm{~g} / \mathrm{cm}^{3}$ for $\varepsilon$-FeOOH $\left(\right.$ Ref. $\left.^{43}\right)$, isostructural with $\delta$-AlOOH]. Thus, the same situation due to pronounced buoyancy would also occur in a "wet-metasomatized" region containing Al-phase H. This implies that Al-phase D and Al-phase $\mathrm{H}$ could be important agents for material transport in the lower mantle. These aluminous DHMS phases might have played an important role in extraction of water from the solid Earth to form the oceans.

Meanwhile, Al-phase D with much higher Al-content, such as super-aluminous phase $\mathrm{D}^{9,10}$, would be stable even in slabs subducting still deeper, but this would also decompose finally into Al-phase $\mathrm{H}$, i.e. solid solutions between $\delta$ - $\mathrm{AlOOH}$ and $\mathrm{MgSiO}_{4} \mathrm{H}_{2}$ (phase $\mathrm{H}$ ), with much higher Al-content to transport hydrogen presumably to the bottom of lower mantle ${ }^{16}$. In addition to such a super-aluminous phase $H$, recently discovered pyrite-type $\mathrm{FeOOH}_{x}(x \leq 1)^{44-46}$, which could be produced in subducted banded-iron-formations, may also be a key to yielding the "wet-metasomatized" region under water-saturated conditions. This iron hydroxide is also promising as a hydrous phase stable at the bottom of lower mantle $\mathrm{e}^{44-46}$ and probably forms solid solutions containing $\mathrm{AlOOH}$ and/or $\mathrm{MgSiO}_{4} \mathrm{H}_{2}$ components in deep subducted slabs ${ }^{46}$. A portion of water released by decomposition of the super-aluminous phase $\mathrm{H}$ and pyrite-type $\mathrm{FeOOH}_{x}$ due to heating at the core-mantle boundary may be spent on incorporating hydrogen into the outer core through the production of iron hydride $\mathrm{FeH}_{x}$. The remainder moving upward may contribute to yielding the water-saturated region in the lower mantle, and may migrate to the surface via Al-phase $\mathrm{D}$ from Al-phase $\mathrm{H}$ produced by reaction with bridgmanite. (In this process, Al-phase $\mathrm{D}$ is implicitly assumed to be formed in the upper region by reaction between Al-phase $\mathrm{H}$ and a high-pressure $\mathrm{SiO}_{2}$ polymorph.) Okuchi ${ }^{47}$ reported that hydrogen is highly-siderophile at high pressure conditions, and suggested that the core-materials (iron ponds) could incorporate a huge amount of hydrogen included in the magma 


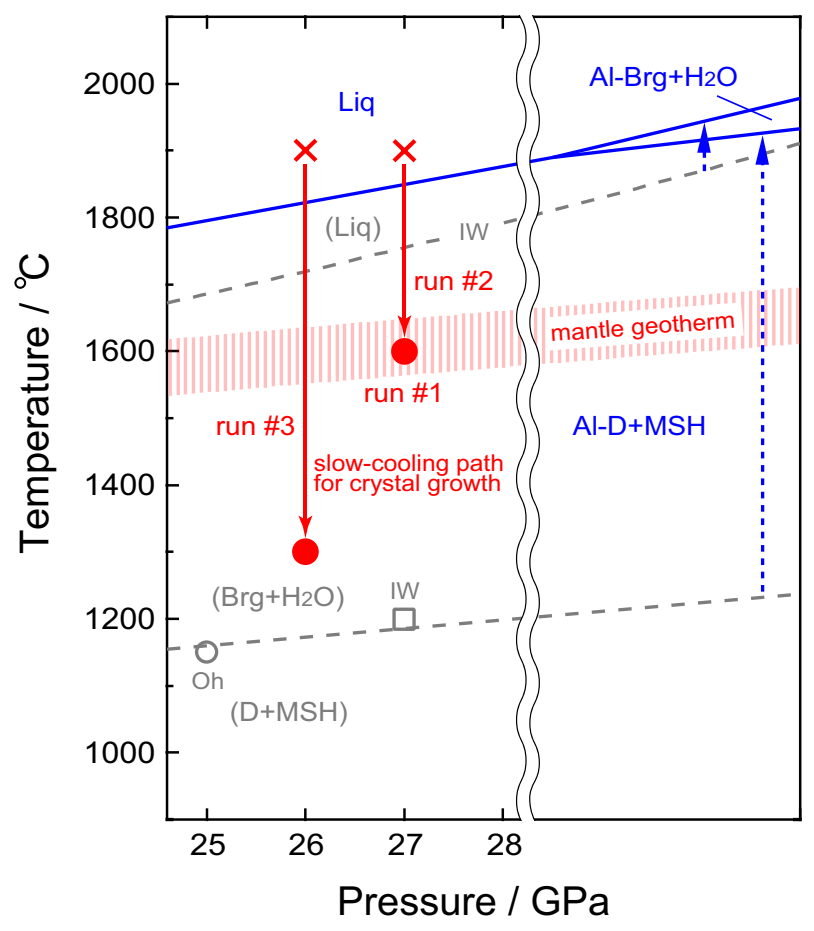

Figure 4. Possible stability relations under water-saturated conditions for the $\mathrm{MgSiO}_{3}$ system (dotted grey lines) and for the $\mathrm{Al}_{2} \mathrm{O}_{3}$-bearing $\mathrm{MgSiO}_{3}$ system (solid blue lines) inferred from the present results and the previous studies ${ }^{6,26}$. For the $\mathrm{Al}_{2} \mathrm{O}_{3}$-bearing $\mathrm{MgSiO}_{3}$ system, about $8 \mathrm{~mol} \%$ of $\mathrm{Al}_{2} \mathrm{O}_{3}$ component is assumed implicitly. Phase abbreviations: $\mathrm{D}$, phase $\mathrm{D} ; \mathrm{Brg}, \mathrm{MgSiO}_{3}$ bridgmanite; $\mathrm{Al}-\mathrm{D}, \mathrm{Al}$-bearing phase $\mathrm{D}$; Al-Brg, Al-bearing $\mathrm{MgSiO}_{3}$ bridgmanite; Liq, liquid; $\mathrm{MSH}$, residual $\mathrm{MgO}-\mathrm{SiO}_{2}-\mathrm{H}_{2} \mathrm{O}$ components. Stability fields with and without parentheses denote those for the $\mathrm{Al}_{2} \mathrm{O}_{3}$-free and the $\mathrm{Al}_{2} \mathrm{O}_{3}$-bearing systems, respectively. The open grey circle, $\mathrm{Oh}$, and the open grey square, IW, show stable existences of D+MSH (Ref. ${ }^{6}$ ) and $\mathrm{Brg}+\mathrm{H}_{2} \mathrm{O}\left(\right.$ Ref. $^{26}$ ) in the $\mathrm{Al}_{2} \mathrm{O}_{3}$-free system, respectively, which could constrain the phase boundary between $\mathrm{D}+\mathrm{MSH}$ and $\mathrm{Brg}+\mathrm{H}_{2} \mathrm{O}$ (in this case, $\mathrm{MSH}$ was identified as superhydrous phase $\mathrm{B}, \mathrm{Mg}_{10} \mathrm{Si}_{3} \mathrm{O}_{18} \mathrm{H}_{4}$, by Ref. ${ }^{6}$ ). The liquidus of $\mathrm{MgSiO}_{3}$ is quoted from Ref. ${ }^{26}$. The red crosses and the solid red arrows represent the soaking temperature $\left(1900^{\circ} \mathrm{C}\right)$ and the slow-cooling paths (from 1900 to $1600^{\circ} \mathrm{C}$ at $27 \mathrm{GPa}$ and from 1900 to $1300^{\circ} \mathrm{C}$ at $26 \mathrm{GPa}$ ) in our crystalgrowth experiments, respectively. The long and short dotted blue arrows show possible shifts of the boundary between $\mathrm{D}+\mathrm{MSH}$ and $\mathrm{Brg}+\mathrm{H}_{2} \mathrm{O}$ and the liquidus toward high temperature by incorporating $\mathrm{Al}_{2} \mathrm{O}_{3}$ component, respectively. The hatched pale-red zone represents the normal mantle-geotherm. Remark: Both melting and dehydration of dense substances are endothermic $(\Delta H>0$, i.e., $\Delta S=\Delta H / T>0)$ and generally accompany the increase in total volume $(\Delta V>0)$ owing to the large volumes of the melts or the released water. Thus, positive Clapeyron slopes $(\mathrm{d} T / \mathrm{d} P=\Delta V / \Delta S>0)$ are adopted for all the phase boundaries.

ocean and the incorporated hydrogen never returns to the silicate Earth. If the Earth's core has been saturated with hydrogen, it would have been released from the outer core over geologic time. However, the geophysical observations combined with the mineral physics data suggested that the core is undersaturated with hydrogen ${ }^{48}$. At present, hydrogen is thus unlikely to be provided from the outer core. In future, however, water continuously released from super-aluminous phase $\mathrm{H}$ and pyrite-type $\mathrm{FeOOH}_{x}$ might saturate the core with hydrogen. If so, hydrogen might come to be released from the outer core and this released hydrogen might also come to migrate to the surface via Al-phase D from Al-phase $\mathrm{H}$.

\section{Methods}

High-pressure experiments. The high-pressure experiments were conducted using a 5000-ton Kawaitype multi-anvil apparatus ${ }^{22}$ installed at the Institute for Planetary Materials, Okayama University. The experimental procedures and techniques are essentially the same as those described in our previous studies ${ }^{49-52}$ as follows. We employed a $6 \mathrm{~mm}$ regular octahedron of sintered $\mathrm{MgO}$ containing $5 \%$ of $\mathrm{Cr}_{2} \mathrm{O}_{3}$ as a pressure-transmitting medium and $\mathrm{LaCrO}_{3}$ as a heating material. The three runs reported here were performed under the different conditions shown in Table 1 . The mixture of the starting materials, including an amount of liquid water suitable for over-saturation, was placed in a Pt capsule and sealed by arc-welding the capsule ends. In particular, liquid water was carefully injected into the capsule using a microsyringe. During arc-welding, the capsule was cooled by wrapping in water-soaked absorbent cotton to prevent evaporation of injected water. The Pt capsule was inserted into the $\mathrm{LaCrO}_{3}$ heater and electrically insulated from the heater by a $\mathrm{MgO}$ spacer. The heater was surrounded with $\mathrm{ZrO}_{2}$ thermal insulator, and then was put into the $\mathrm{MgO}$ octahedron. This cell assembly was set in the anvil assembly of tungsten carbide cubes with truncated edge lengths of $2 \mathrm{~mm}$, and then was compressed 
up to the target pressure $(26$ or $27 \mathrm{GPa}$ ) at room temperature. The temperature was then raised to the target maximum temperature $\left(1600\right.$ or $\left.1900{ }^{\circ} \mathrm{C}\right)$ in each run at a rate of $35^{\circ} \mathrm{C} / \mathrm{min}$. The temperature was controlled with a W97\%Re3\%-W75\%Re25\% thermocouple, whose junction was put at the midpoint of the outer surface of the Pt capsule. No correction was made for the pressure effect on emf. After being exposed to the different thermal history in each run (Table 1), the products were quenched at 1300 or $1600^{\circ} \mathrm{C}$ by shutting off the electric power supply. The pressure was released slowly and the products were recovered at ambient conditions. The recovered samples were mounted with epoxy and polished for the chemical analyses using a JEOL JCMA-733II electron probe microanalyzer. For the analyses, the irradiated electron beam was focused to $5 \mu \mathrm{m}$ in diameter, sufficiently smaller than area sizes of analyzed crystals, under operation conditions of a $15 \mathrm{kV}$ acceleration voltage and a $10 \mathrm{nA}$ beam current. No contamination from the cell assembly materials into the products was detected from qualitative electron probe microanalyses. For the phase identification, the polished samples were also characterized by a Rigaku RINT RAPID-R microfocus X-ray diffractometer with Cu Ka radiation $(\lambda=1.54184 \AA)$ operated at $40 \mathrm{kV}$ and $200 \mathrm{~mA}$.

Single-crystal X-ray diffraction intensity measurements and structure refinements. The single-crystal X-ray diffraction intensity measurements, data processing and structure refinements were conducted according to essentially the same procedures and techniques as those described in our previous studies ${ }^{49-58}$ as follows. A single crystal with a size of $75 \times 45 \times 20 \mu \mathrm{m}^{3}$ produced in the run $\# 3$ was selected and then mounted on the tip of a glass fiber for X-ray diffraction intensity measurements using a graphite-monochromatized Mo Ka radiation $(\lambda=0.71069 \AA)$. The measurements were conducted at room temperature $(296 \mathrm{~K})$ using a Rigaku AFC7R four-circle diffractometer operated at $60 \mathrm{kV}$ and $250 \mathrm{~mA}$. The unit-cell parameters were determined by the least-squares method from a set of 27 reflections within the range of $38^{\circ} \leq 2 \theta \leq 50^{\circ}$. The intensity data of a total of 1961 reflections within $2^{\circ} \leq 2 \theta \leq 100^{\circ}$ were collected using the continuous $\omega-2 \theta$ scan mode and corrected for Lorentz-polarization factors and absorption effects ( $\psi$-scan method). The unit-cell parameters were calculated as $a=4.8372(8) \AA, b=4.8359(11) \AA, c=4.3236(5) \AA, \alpha=90.000(14)^{\circ}, \beta=90.005(12)^{\circ}$ and $\gamma=119.981(12)^{\circ}$ without any constraints, agreeing with a trigonal cell. The final unit-cell parameters were determined as $a=4.8379$ (4) $\AA$ and $c=4.3236(4) \AA$ under the constraints of trigonal setting. Intensity statistics, indeed, showed Laue symmetry $\overline{3} 1 \mathrm{~m}$ (trigonal cell). The intensity data were averaged in this Laue symmetry to give 351 unique reflections. Of these, unique reflections with $\left|F_{\mathrm{O}}\right| \leq 3 \sigma_{\mathrm{F}}$ were eliminated, where $\sigma_{\mathrm{F}}$ is the standard deviation for observed structure factor $\left|F_{\mathrm{o}}\right|$. Even if unique reflections had intensities of $\left|F_{\mathrm{o}}\right|>3 \sigma_{\mathrm{F}}$ after averaging, those averaged from data set of equivalent reflections including reflection $(\mathrm{s})$ with $\left|F_{\mathrm{O}}\right| \leq 3 \sigma_{\mathrm{F}}$ were also discarded since these reflections were potentially affected by multiple scattering as in Refs. ${ }^{51-56}$. Finally, 167 unique reflections were used in the present refinements.

The crystal structure was determined by the direct method using the program SIR97 (Ref. ${ }^{59}$ ) and refined by minimizing the function $\sum \sigma_{\mathrm{F}}^{-2}\left(\left|F_{\mathrm{O}}\right|-\left|F_{\mathrm{c}}\right|\right)^{2}$ using the full matrix least-squares program RADY ${ }^{60}$. Among the space groups subjected to Laue symmetry $\overline{3} 1 \mathrm{~m}$, the possible ones are $P 31 \mathrm{~m}, P 312$ and $P 31 \mathrm{~m}$ because no systematic absences were observed. We selected the centrosymmetric space group $P \overline{3} 1 m$, adopted in $\mathrm{Al}$-free phase $\mathrm{D}^{23-25}$, because the structure refinements assuming the remaining two space groups resulted in unsuccessful convergence with larger reliability indices. Indeed, in the difference Fourier synthesis after the final refinement assuming $P \overline{3}$ $1 \mathrm{~m}$, no significant residual electron densities were observed around the $\mathrm{M}, \mathrm{S}$ and $\mathrm{O}$ sites; thus, site-splitting due to symmetry reduction to non-centrosymmetric subgroup $P 31 \mathrm{~m}$ or $P 312$ is most unlikely. $\mathrm{H}$ atom was excluded from the structure refinements because of its low X-ray scattering power. Scattering factors of $\mathrm{Mg}^{2+}, \mathrm{Al}^{3+}, \mathrm{Si}^{4+}$ (Table 6.1.1.3 in International Tables for Crystallography $\left.{ }^{61}\right)$, and $\mathrm{O}^{2-}\left(\right.$ Tokonami $\left.^{62}\right)$ were used. Anomalous dispersion coefficients for each scattering factor were taken from Table 4.2.6.8 in International Tables for Crystallography ${ }^{61}$. Several correction models for the secondary extinction effects were attempted during the refinements, and the isotropic correction of Type $\mathrm{I}^{63,64}$ with a Gaussian mosaic spread distribution model yielded the best fit.

In super-aluminous phase $\mathrm{D}^{9,10}$ (simplified formula $\mathrm{Al}_{2} \mathrm{SiO}_{6} \mathrm{H}_{2}$ ), the following three ${ }^{10}$ or four ${ }^{9}$ symmetrically distinct octahedral-sites are partially occupied by a disordered distribution of Al and Si: M-site (Wyckoff position $1 a$ ) and S-site (2d), which are also occupied in Al-free phase $\mathrm{D}^{23-25}$ (simplified formula $\mathrm{MgSi}_{2} \mathrm{O}_{6} \mathrm{H}_{2}$ ), and the one $(2 c)^{10}$ or two $(2 c, 1 b)^{9}$ additional octahedral sites, which are vacant in Al-free phase $\mathrm{D}$. The difference Fourier synthesis for the present $\mathrm{Al}$-phase $\mathrm{D}$, however, showed that no significant residual electron density peak is detected on these additional octahedral sites, which indicates that cations are distributed only on M- and $\mathrm{S}$-sites as in $\mathrm{Al}$-free phase $\mathrm{D}^{23-25}$. The structure refinements were therefore performed by varying $P\left({ }^{\mathrm{M}} \mathrm{Mg}\right)$ as the only valuable site occupancy parameter under the following constraints to keep the chemical composition from the electron probe microanalyses: $P\left({ }^{\mathrm{S}} \mathrm{Si}\right) \equiv 0.715$ (fix), $P\left({ }^{\mathrm{S}} \mathrm{Al}\right) \equiv 0.135$ (fix), $P\left({ }^{\mathrm{S}} \mathrm{Mg}\right) \equiv 0.625-0.5 \times P\left({ }^{\mathrm{M}} \mathrm{Mg}\right.$ ), where the superscripts $M$ and $S$ represent the occupied sites of the cations. The final structure refinement converged smoothly to $R=0.0320$ and $\mathrm{w} R=0.0319$ with anisotropic displacement parameters. The resulting $P\left({ }^{\mathrm{M}} \mathrm{Mg}\right)$ is $0.979(8)$, indicating that $\mathrm{M}$ - and S-sites both are almost full occupied. In the final difference Fourier synthesis, the residual electron density peaks with a height of $0.36 \mathrm{e}^{-3}$ (Fig. 3d) were observed at equivalent positions of the coordinates $(0.495,0,0.124)$, located $0.91 \AA$ and $1.80 \AA$ away from adjacent $O$ atoms. These distances are reasonable as $\mathrm{H}-\mathrm{O}$ (donor) and $\mathrm{H}$... O (acceptor) bond lengths, respectively, which was also confirmed from the bond valence calculations ${ }^{27}$. We therefore assigned the peaks to $\mathrm{H}$ atoms.

The summary of crystallographic data, data-collection and refinement parameters is given in Supplementary Table S1. The refined structural parameters and the selected interatomic distances and angles are listed in Tables 3 and 4, respectively. Crystallographic Information File (CIF) is deposited in the Cambridge Structural Database (CSD) (Deposition No. 2118607). 
Received: 29 October 2021; Accepted: 31 January 2022

Published online: 04 March 2022

\section{References}

1. Iwamori, H. Transportation of $\mathrm{H}_{2} \mathrm{O}$ and melting in subduction zones. Earth Planet. Sci. Lett. 160, 65-80 (1998).

2. Karato, S.-I., Paterson, M. S. \& FitzGerald, J. D. Rheology of synthetic olivine aggregates: Influence of grain size and water. J. Geophys. Res. 91(B8), 8151-8176 (1986).

3. Mei, S. \& Kohlstedt, D. L. Influence of water on plastic deformation of olivine aggregates: 1. Diffusion creep regime. J. Geophys. Res. 105(B9), 21457-21469 (2000).

4. Mei, S. \& Kohlstedt, D. L. Influence of water on plastic deformation of olivine aggregates: 2. Dislocation creep regime. J. Geophys. Res. 105(B9), 21471-21481 (2000).

5. Ohtani, E. et al. A new hydrous silicate, a water reservoir, in the upper part of the lower mantle. Geophys. Res. Lett. 24, 1047-1050 (1997).

6. Ohtani, E., Mizobata, H. \& Yurimoto, H. Stability of dense hydrous magnesium silicate phases in the systems $\mathrm{Mg}_{2} \mathrm{SiO}_{4}-\mathrm{H}_{2} \mathrm{O}$ and $\mathrm{MgSiO}_{3}-\mathrm{H}_{2} \mathrm{O}$ at pressures up to $27 \mathrm{GPa}$. Phys. Chem. Miner. 27, 533-544 (2000).

7. Ohtani, E., Toma, M., Litasov, K., Kubo, T. \& Suzuki, A. Stability of dense hydrous magnesium silicate phases and water storage capacity in the transition zone and lower mantle. Phys. Earth Planet. Inter. 124, 105-117 (2001).

8. Ghosh, S. \& Schmidt, M. W. Melting of phase D in the lower mantle and implications for recycling and storage of $\mathrm{H}_{2} \mathrm{O}$ in the deep mantle. Geochim. Cosmochim. Acta 145, 72-88 (2014).

9. Pamato, M. G. et al. Lower-mantle water reservoir implied by the extreme stability of a hydrous aluminosilicate. Nat. Geosci. 8, 75-79 (2015).

10. Boffa Ballaran, T., Frost, D. J., Miyajima, N. \& Heidelbach, F. The structure of a super-aluminous version of the dense hydrousmagnesium silicate phase D. Am. Mineral. 95, 1113-1116 (2010).

11. Tsuchiya, J. First principles prediction of a new high-pressure phase of dense hydrous magnesium silicates in the lower mantle. Geophys. Res. Lett. 40, 4570-4573 (2013).

12. Nishi, M. et al. Stability of hydrous silicate at high pressures and water transport to the deep lower mantle. Nat. Geosci. 7, 224-227 (2014).

13. Ohtani, E., Amaike, Y., Kamada, S., Sakamaki, T. \& Hirao, N. Stability of hydrous phase $\mathrm{H} \mathrm{MgSiO}_{4} \mathrm{H}_{2}$ under lower mantle conditions. Geophys. Res. Lett. 41, 8283-8287 (2014).

14. Tsuchiya, J. \& Mookherjee, M. Crystal structure, equation of state, and elasticity of phase $\mathrm{H}\left(\mathrm{MgSiO}_{4} \mathrm{H}_{2}\right)$ at Earth's lower mantle pressures. Sci. Rep. 5, 15534 (2015).

15. Ohira, I. et al. The influence of $\delta$-(Al, Fe)OOH on seismic heterogeneities in Earth's lower mantle. Sci. Rep. 11, 12036 (2021).

16. Ohira, I. et al. Stability of a hydrous $\delta$-phase, $\mathrm{AlOOH}-\mathrm{MgSiO}_{2}(\mathrm{OH})_{2}$, and a mechanism for water transport into the base of lower mantle. Earth Planet. Sci. Lett. 401, 12-17 (2014).

17. Walter, M. J. et al. The stability of hydrous silicates in Earth's lower mantle: Experimental constraints from the systems $\mathrm{MgO}_{-} \mathrm{SiO}_{2}-$ $\mathrm{H}_{2} \mathrm{O}$ and $\mathrm{MgO}-\mathrm{Al}_{2} \mathrm{O}_{3}-\mathrm{SiO}_{2}-\mathrm{H}_{2} \mathrm{O}$. Chem. Geol. 418, 16-29 (2015)

18. Yuan, H. et al. Stability of Fe-bearing hydrous phases and element partitioning in the system $\mathrm{MgO}_{-}-\mathrm{Al}_{2} \mathrm{O}_{3}-\mathrm{Fe}_{2} \mathrm{O}_{3}-\mathrm{SiO}_{2}-\mathrm{H}_{2} \mathrm{O}$ in Earth's lowermost mantle. Earth Planet. Sci. Lett. 524, 115714 (2019).

19. Kubo, A. \& Akaogi, M. Post-garnet transitions in the system $\mathrm{Mg}_{4} \mathrm{Si}_{4} \mathrm{O}_{12}-\mathrm{Mg}_{3} \mathrm{Al}_{2} \mathrm{Si}_{3} \mathrm{O}_{12}$ up to 28 GPa: Phase relations of garnet, ilmenite and perovskite. Phys. Earth Planet. Inter. 121, 85-102 (2000).

20. Irifune, T. Absence of an aluminous phase in the upper part of the Earth's lower mantle. Nature 370, 131-133 (1994).

21. Ringwood, A. E. In Advances in Earth Sciences (ed. Hurley, P.) 287-356 (MIT Press, 1966).

22. Kawai, N., Togaya, M. \& Onodera, A. A new device for high pressure vessels. Proc. Jpn. Acad. 49, 623-626 (1973).

23. Yang, H., Prewitt, C. T. \& Frost, D. J. Crystal structure of the dense hydrous magnesium silicate, phase D. Am. Mineral. 82, 651-654 (1997).

24. Kudoh, Y., Nagase, T., Mizobata, H. \& Ohtani, E. Structure and crystal chemistry of phase G, a new hydrous magnesium silicate synthesized at $22 \mathrm{GPa}$ and $1050^{\circ} \mathrm{C}$. Geophys. Res. Lett. 24, 1051-1054 (1997).

25. Suzuki, A. et al. Neutron diffraction study of hydrous phase G: Hydrogen in the lower mantle hydrous silicate, phase G. Geophys. Res. Lett. 28, 3987-3990 (2001).

26. Ito, E. \& Weidner, D. J. Crystal growth of $\mathrm{MgSiO}_{3}$ perovskite. Geophys. Res. Lett. 13, 464-466 (1986).

27. Gagné, O. C. \& Hawthorne, F. C. Comprehensive derivation of bond-valence parameters for ion pairs involving oxygen. Acta Crystallogr. B71, 562-578 (2015)

28. Kudo, R. \& Ito, E. Melting relations in the system $\mathrm{Mg}_{4} \mathrm{Si}_{4} \mathrm{O}_{12}(\mathrm{En})-\mathrm{Mg}_{3} \mathrm{Al}_{2} \mathrm{Si}_{3} \mathrm{O}_{12}(\mathrm{Py})$ at high pressures. Phys. Earth Planet. Inter. 96 , 159-169 (1996).

29. Andrault, D. A., Neuville, D. R., Flank, A.-M. \& Wang, Y. Cation sites in Al-rich $\mathrm{MgSiO}_{3}$ perovskites. Am. Mineral. 83, 1045-1053 (1998).

30. Bolfan-Casanova, N., Keppler, H. \& Rubie, D. C. Water partitioning at $660 \mathrm{~km}$ depth and evidence for very low water solubility in magnesium silicate perovskite. Geophys. Res. Lett. 30, 1905. https://doi.org/10.1029/2003GL017182 (2003).

31. Murakami, M., Hirose, K., Yurimoto, H., Nakashima, S. \& Takafuji, N. Water in earth's lower mantle. Science 295, 1885-1887 (2002)

32. Ono, S., Ito, E. \& Katsura, T. Mineralogy of subducted basaltic crust (MORB) from 25 to 37 GPa, and chemical heterogeneity of the lower mantle. Earth Planet. Sci. Lett. 190, 57-63 (2001).

33. Hirose, K. \& Fei, Y. Subsolidus and melting phase relations of basaltic composition in the uppermost lower mantle. Geochim. Cosmochim. Acta 66, 2099-2108 (2002).

34. Shieh, S. R., Mao, H.-K., Hemley, R. J. \& Ming, L. C. Decomposition of phase D in the lower mantle and the fate of dense hydrous silicates in subducting slabs. Earth Planet. Sci. Lett. 159, 13-23 (1998).

35. Liu, X., Matsukage, K. N., Nishihara, Y., Suzuki, T. \& Takahashi, E. Stability of the hydrous phases of Al-rich phase D and Al-rich phase $\mathrm{H}$ in deep subducted oceanic crust. Am. Mineral. 104, 64-72 (2019).

36. Litasov, K. D., Ohtani, E., Suzuki, A. \& Funakoshi, K. The compressibility of Fe- and Al-bearing phase D to $30 \mathrm{GPa}$. Phys. Chem. Miner. 34, 159-167 (2007).

37. Litasov, K. D., Ohtani, E., Nishihara, Y., Suzuki, A. \& Funakoshi, K. Thermal equation of state of Al- and Fe-bearing phase D. J. Geophys. Res. 113(B8), B08205 (2008).

38. Rosa, A. D., Sanchez-Valle, C. \& Ghosh, S. Elasticity of phase D and implication for the degree of hydration of deep subducted slabs. Geophys. Res. Lett. 39, L06304 (2012).

39. Chang, Y.-Y. et al. Spin transition of $\mathrm{Fe}^{3+}$ in Al-bearing phase D: An alternative explanation for small-scale seismic scatterers in the mid-lower mantle. Earth Planet. Sci. Lett. 382, 1-9 (2013).

40. Ito, E., Takahashi, E. \& Matsui, Y. The mineralogy and chemistry of the lower mantle: An implication of the ultrahigh-pressure phase relations in the system $\mathrm{MgO}-\mathrm{FeO}-\mathrm{SiO}_{2}$. Earth Planet. Sci. Lett. 67, 238-248 (1984).

41. Bindi, L., Nishi, M., Tsuchiya, J. \& Irifune, T. Crystal chemistry of dense hydrous magnesium silicates: The structure of phase H, $\mathrm{MgSiH}_{2} \mathrm{O}_{4}$, synthesized at $45 \mathrm{GPa}$ and $1000^{\circ} \mathrm{C}$. Am. Mineral. 99, 1802-1805 (2014). 
42. Komatsu, K., Kuribayashi, T., Sano, A., Ohtani, E. \& Kudoh, Y. Redetermination of the high-pressure modification of AlOOH from single-crystal synchrotron data. Acta Crystallogr. E62, i216-i218 (2015).

43. Xu, C., Nishi, M. \& Inoue, T. Solubility behavior of $\delta$ - AlOOH and $\varepsilon-F e O O H$ at high pressures. Am. Mineral. 104, 1416-1420 (2019).

44. Hu, Q. et al. Dehydrogenation of goethite in Earth's deep lower mantle. Proc. Natl. Acad. Sci. U.S.A. 114, 1498-1501 (2017).

45. Liu, J. et al. Hydrogen-bearing iron peroxide and the origin of ultralow-velocity zones. Nature 551, 494-497 (2017).

46. Nishi, M., Kuwayama, Y., Tsuchiya, J. \& Tsuchiya, T. The pyrite-type high-pressure form of FeOOH. Nature 547, 205-208 (2017).

47. Okuchi, T. Hydrogen partitioning into molten iron at high pressure: Implications for Earth's core. Science 278, 1781-1784 (1997).

48. Terasaki, H. et al. Stability of Fe-Ni hydride after the reaction between Fe-Ni alloy and hydrous phase ( $\delta$-AlOOH) up to $1.2 \mathrm{Mbar}$ : Possibility of H contribution to the core density deficit. Phys. Earth Planet. Inter. 194-195, 18-24 (2012).

49. Nakatsuka, A., Yoshiasa, A., Yamanaka, T. \& Ito, E. Structure refinement of a birefringent Cr-bearing majorite $\mathrm{Mg}_{3}\left(\mathrm{Mg}_{0.34} \mathrm{Si}_{0.34} \mathrm{Al}_{0.18} \mathrm{Cr}_{0.14}\right)_{2} \mathrm{Si}_{3} \mathrm{O}_{12}$. Am. Mineral. 84, 199-202 (1999).

50. Nakatsuka, A. et al. Symmetry change of majorite solid-solution in the system $\mathrm{Mg}_{3} \mathrm{Al}_{2} \mathrm{Si}_{3} \mathrm{O}_{12}-\mathrm{MgSiO}_{3}$. Am. Mineral. 84, 1135-1143 (1999).

51. Nakatsuka, A. et al. Temperature dependence of crystal structure of $\mathrm{CaGeO}_{3}$ high-pressure perovskite phase and experimental determination of its Debye temperatures studied by low- and high-temperature single-crystal X-ray diffraction. Am. Mineral. 100, 1190-1202 (2015).

52. Nakatsuka, A. et al. Incorporation mechanism of $\mathrm{Fe}$ and $\mathrm{Al}$ into bridgmanite in a subducting mid-ocean ridge basalt and its crystal chemistry. Sci. Rep. 11, 22839. https://doi.org/10.1038/s41598-021-00403-6 (2021).

53. Nakatsuka, A. et al. Static disorders of atoms and experimental determination of Debye-temperature in pyrope: Low- and hightemperature single crystal X-ray diffraction study. Am. Mineral. 96, 1593-1605 (2011).

54. Nakatsuka, A., Arima, H., Ohtaka, O., Fujiwara, K. \& Yoshiasa, A. Crystal structure of $\mathrm{SrGeO}_{3}$ in the high-pressure perovskite-type phase. Acta Crystallogr. E71, 502-504 (2015).

55. Nakatsuka, A., Sugiyama, K., Yoneda, A., Fujiwara, K. \& Yoshiasa, A. Crystal structure of post-perovskite-type $\mathrm{CaIrO}_{3}$ reinvestigated: New insights into atomic thermal vibration behaviors. Acta Crystallogr. E71, 1109-1113 (2015).

56. Nakatsuka, A., Yoshiasa, A., Fujiwara, K. \& Ohtaka, O. Variable-temperature single-crystal X-ray diffraction study of $\mathrm{SrGeO}_{3}$ high-pressure perovskite phase. J. Mineral. Petrol. Sci. 113, 280-285 (2018).

57. Nakatsuka, A., Ikuta, Y., Yoshiasa, A. \& Iishi, K. Single crystal X-ray diffraction study of the vanadate garnet $\mathrm{Ca}_{2} \mathrm{NaZn}_{2} \mathrm{~V}_{3} \mathrm{O}_{12}$. Mater. Res. Bull. 39, 949-956 (2004).

58. Nakatsuka, A., Chaya, H. \& Yoshiasa, A. Crystal structure of single-crystal $\mathrm{CaGeO}_{3}$ tetragonal garnet synthesized at $3 \mathrm{GPa}$ and $1000{ }^{\circ} \mathrm{C}$. Am. Mineral. 90, 755-757 (2005).

59. Altomare, A. et al. SIR97: A new tool for crystal structure determination and refinement. J. Appl. Crystallogr. 32, 115-119 (1999).

60. Sasaki, S. RADY: A Fortran Program for the Least-Squares Refinement of Crystal Structures (National Laboratory for High Energy Physics, 1987).

61. International Tables for Crystallography Vol. C (ed Wilson, A. J. C.) (Kluwer Academic Publishers, 1992).

62. Tokonami, M. Atomic scattering factor for $\mathrm{O}^{2-}$. Acta Crystallogr. 19, 486 (1965).

63. Becker, P. J. \& Coppens, P. Extinction within the limit of validity of the Darwin transfer equations. I. General formalisms for primary and secondary extinction and their application to spherical crystals. Acta Crystallogr. A30, 129-147 (1974).

64. Becker, P. J. \& Coppens, P. Extinction within the limit of validity of the Darwin transfer equations. II. Refinement of extinction in spherical crystals of $\mathrm{SrF}_{2}$ and LiF. Acta Crystallogr. A30, 148-153 (1974).

\section{Acknowledgements}

The present study was supported by JSPS KAKENHI (Grant Nos. JP15K05344, JP22244068, JP15740317 and JP12740299). The high-pressure experiments and microfocus X-ray diffraction measurements were performed using joint-use facilities of the Institute for Planetary Materials, Okayama University. We also acknowledge Dr. M. J. Walter of Carnegie Institution for Science for critical reading of the manuscript and Y. Shibata of Hiroshima University for electron probe microanalyses.

\section{Author contributions}

A.N. designed the study and compiled the data. A.N. and E.I. conducted the high-pressure experiments, and A.N. performed the microfocus X-ray diffraction measurements for the recovered samples. A.N. and A.Y. performed the single-crystal X-ray diffraction experiments and crystal structure analyses. M.O. analyzed the chemical compositions of the samples from the electron probe microanalyses. The manuscript was written by A.N., revised by E.I. and finally reviewed by all authors.

\section{Competing interests}

The authors declare no competing interests.

\section{Additional information}

Supplementary Information The online version contains supplementary material available at https://doi.org/ 10.1038/s41598-022-07007-8.

Correspondence and requests for materials should be addressed to A.N.

Reprints and permissions information is available at www.nature.com/reprints.

Publisher's note Springer Nature remains neutral with regard to jurisdictional claims in published maps and institutional affiliations. 
(c) (i) Open Access This article is licensed under a Creative Commons Attribution 4.0 International cc) License, which permits use, sharing, adaptation, distribution and reproduction in any medium or format, as long as you give appropriate credit to the original author(s) and the source, provide a link to the Creative Commons licence, and indicate if changes were made. The images or other third party material in this article are included in the article's Creative Commons licence, unless indicated otherwise in a credit line to the material. If material is not included in the article's Creative Commons licence and your intended use is not permitted by statutory regulation or exceeds the permitted use, you will need to obtain permission directly from the copyright holder. To view a copy of this licence, visit http://creativecommons.org/licenses/by/4.0/.

(C) The Author(s) 2022 